OPEN ACCESS

Edited by:

Libin Zhang,

Institute of Oceanology (CAS), China

Reviewed by:

Qinzeng Xu,

First Institute of Oceanography, Ministry of Natural Resources, China

Reiji Masuda

Kyoto University, Japan

*Correspondence:

Nobuharu Inaba

inaba-n@ceri.go.jp

Specialty section:

This article was submitted to

Marine Fisheries, Aquaculture and Living Resources,

a section of the journal

Frontiers in Marine Science

Received: 24 March 2021

Accepted: 24 May 2021

Published: 22 June 2021

Citation:

Inaba N, Matsumoto T, Kawai H,

Anaguchi $Y$ and Matsuno K (2021)

Predation of Juvenile Japanese Sea Cucumber Apostichopus japonicus

by Kelp Crab Pugettia ferox.

Front. Mar. Sci. 8:684989.

doi: 10.3389/fmars.2021.684989

\section{Predation of Juvenile Japanese Sea Cucumber Apostichopus japonicus by Kelp Crab Pugettia ferox}

\author{
Nobuharu Inaba ${ }^{1 *}$, Takuma Matsumoto ${ }^{2}$, Hiroshi Kawai ${ }^{1}$, Yuji Anaguchi $^{3}$ and \\ Kohei Matsuno ${ }^{2,4}$ \\ ${ }^{1}$ Civil Engineering Research Institute for Cold Region, Public Works Research Institute, Sapporo, Japan, ${ }^{2}$ Faculty/Graduate \\ School of Fisheries Sciences, Hokkaido University, Hakodate, Japan, ${ }^{3}$ Ocean Construction Co., Ltd., Kurashiki, Japan, \\ ${ }^{4}$ Arctic Research Center, Hokkaido University, Sapporo, Japan
}

The predation of commercially important Japanese sea cucumber Apostichopus japonicus by the kelp crab Pugettia ferox, widely distributed in coastal northeast Asia, was examined in field sampling and laboratory experiments. The ossicles of $A$. japonicus were detected from the stomach contents of a natural population of $P$. ferox at the rate of $32.4 \%$ of 68 individuals collected within artificial intermediate sea cucumber reefs for releasing hatchery-produced juveniles in December 2018. In the following laboratory experiments, a high mortality rate $\left(7.7 \pm 2.4\right.$ individuals day $\left.{ }^{-1}\right)$ of juvenile $A$. japonicus $(15.35 \pm 2.47 \mathrm{~mm})$ was observed despite the different sizes and sex of $P$. ferox tested. It was also confirmed that a maximum of five sea cucumbers was killed and cut into small pieces within the first $2 \mathrm{~h}$. Smaller and younger $P$. ferox individuals (adolescent) between carapace widths of 14.2-17.8 mm actively decorated themselves using pieces of chopped sea cucumber after feeding. Attached pieces of sea cucumber were observed to be fully eaten within a week, suggesting a possible strategy by $P$. ferox of short-term food storage as well as mimicry. This study demonstrates considerable evidence that predation mortality by sufficiently mobile $P$. ferox on commercially important $A$. japonicus can be significant, causing high mortality at the early life stage in the natural environment, especially in areas releasing hatchery-produced juveniles. It is also worth noting that the utilization of freshly chopped sea cucumbers as decoration material and food storage is a unique and novel ecological trait of $P$. ferox.

Keywords: sea cucumber, Apostichopus japonicus, Pugettia ferox, predation, decorator crab

\section{INTRODUCTION}

The Japanese sea cucumber Apostichopus japonicus (Selenka, 1867), an Echinoderm of the class Holothuroidea, is widely distributed along the coast of southern far-east Russia, South Korea, northern China, Japan, and United States (Choo, 2008). A. japonicus is one of the common temperate sea cucumber species that has been harvested, traded, and traditionally consumed as seafood and a tonic in south-east Asia for centuries (Akamine, 2015). Japan has exported sea cucumbers, including A. japonicus, to China as a major commodity at least for 350 years (Akamine, 2004). In particular, A. japonicus harvested from Hokkaido, the northern island of Japan, is regarded as the highest quality due to characteristics of a greater number, large lined-up warts, and thicker flesh 
(Brown and Eddy, 2015). The declining wild population of sea cucumber by overfishing, habitat loss, and human-induced pollution have been described by Purcell et al. (2013), and A. japonicus was also added to the ICUN Red List of threatened species as "Endangered" in the same year (Mercier and Hamel, 2013). Although Japan has taken the initiative in conservation measures such as regulating the total annual catch, harvest size and adopting a closed season to promote reproduction, the wild stocks of A. japonicus have declined at least 30\% in the past 30 years (Choo, 2008). The release of hatcheryproduced juveniles is promoted to enhance the wild population of A. japonicus (Battaglene, 1999; Purcell, 2004). To rebuild the wild stocks around the coast of Hokkaido, the vigorous release of juveniles has been carried out (Hokkaido Government, 2020).

Predation is one of the determining factors that influence the benthic invertebrate community structure in aquatic ecosystems (Bell et al., 2005). Numerous reports have documented that early juveniles of invertebrates such as bivalves, decapod crustaceans, and echinoderms, etc., are vulnerable to predation, and a significant number of juveniles are assumed to be killed by predators (Gosselin and Qian, 1997). Aquatic animals, including marine mammals, sea birds, fish, asteroids, crustaceans, and gastropods, have also been documented to prey on holothurians (Francour, 1997). However, few studies have documented the significance of predators on A. japonicus ( $\mathrm{Yu}$ et al., 2015). The kelp crab Pugettia ferox, recently reclassified as a new species, is a much larger crab species than formerly assigned Pugettia quadridens, which distributes more northward (Ohtsuchi and Kawamura, 2019). P. quadridens is known as a notorious predatory crab negatively affecting fishery resources such as juveniles of Ezo abalone and sea urchins in Japan (Shibui, 1971; Kawai and Agatsuma, 1996; Hoshikawa, 2003). On our study site, a remarkable increase of the $P$. ferox population within artificial intermediate sea cucumber reefs for releasing hatchery-produced juvenile A. japonicus has been observed (Figures 1A-C), and the ossicles of A. japonicus were detected continuously from the stomach contents of P. ferox (Figure 1D) as well as active predation (Figure 1E and Supplementary Movie 1). To our best knowledge, there is no literature on quantitative predation on $A$. japonicus by $P$. ferox. This report provides novel findings of predation on $A$. japonicus juveniles by $P$. ferox through microscopic observations of stomach contents in the natural population and predation experiments.

\section{MATERIALS AND METHODS}

\section{Field Sampling and Observation of Stomach Content}

A total of 68 P. ferox were collected in December 2018 from artificial intermediate sea cucumber reefs, deployed at a depth of $4-5 \mathrm{~m}$ within a fishing port $(41.2744 \mathrm{~N}, 140.1452 \mathrm{E})$ located in southwestern Hokkaido, Japan. Samples were preserved in $70 \%$ ethanol immediately after sampling in the field for later measurements and stomach content observations. Maximum carapace width $(\mathrm{CW})$ and post-pseudorostral carapace length
(PCL), and wet weight were measured as body size indexes (Figure 2). After the measurement, the stomach of each P. ferox was dissected using a scalpel. The stomach contents were placed into a microtube and dissolved in a sodium hypochlorite solution (NaClO, 5\%). Then, microscopic observation using Axiovert 135 (Zeiss, Germany) was performed to check whether the ossicles of A. japonicus exist in the samples.

\section{Laboratory Predation Experiment}

Pugettia ferox ( $n=9$, four Males, five Females) collected in the same reefs mentioned above at the end of June 2019 were brought back to the laboratory alive. $P$. ferox were kept individually in clear aquaria $(31 \mathrm{~cm}$ length $\times 18 \mathrm{~cm}$ width) filled to a depth of $5 \mathrm{~cm}$ of seawater at $13 \pm 1^{\circ} \mathrm{C}$ which is the local water temperature of releasing $A$. japonicus juveniles, under a $12 \mathrm{~h}$ light/12 h dark cycle (12:12 LD) without feeding for a week before the predation experiments. An aquaria with no P. ferox was also prepared as control (C). CW, PCL, cheliped propodus length (CPL), and wet weight of $P$. ferox were measured as indexes of body size (Figure 2 and Table 1). Body length, width, and wet weight of $A$. japonicus juveniles used as prey were also measured in advance. All A. japonicus were immersed in L-menthol for 2030 min (Hatanaka and Tanimura, 1994), and the body length and width were measured, then standard body length (SBL), which is a widely used method for accurate measurement of sea cucumbers, was estimated (Yamana et al., 2011). A digital vernier caliper was used for all the measurements to the nearest $0.1 \mathrm{~mm}$. A. japonicus juveniles used in this study were purchased from Hokkaido Aquaculture Promotion Corporation. Ten A. japonicus individuals were randomly selected and placed into each aquaria for predation experiments. The average SBL and wet weight of $A$. japonicus used were $15.35 \pm 2.47 \mathrm{~mm}$ $($ Mean $\pm \mathrm{SD}$ ) varied from 10.82 to $19.99 \mathrm{~mm}$, and $0.1 \pm 0.04 \mathrm{~g}$ varied from 0.03 to $0.23 \mathrm{~g}$, respectively. A. japonicus were counted after $12 \mathrm{~h}$ (the end of a light cycle) and $24 \mathrm{~h}$ (the end of a dark cycle). All the $P$. ferox decorated with a piece of A. japonicus were observed continuously for another week in the same aquaria after removing the remaining $A$. japonicus and organic residuals. The densities of $A$. japonicus juveniles per unit area adopted in the experiments were based on the densities observed in the field. The depth of seawater in the aquaria applied was to eliminate the inaccessibility due to vertical attachment by $A$. japonicus during the experiments. The experiments mentioned above were repeated three times and then preserved in $70 \%$ ethanol to examine the ontogenetic stages (Ohtsuchi and Kawamura, 2019).

\section{Statistical Analysis}

The differences in body size indexes of CW, PCL, and wet weight between the ossicle-detected and not-detected groups from the field sampling and mortality rate between day and night, male and female, and ontogenetic stages (adolescent and full-grown) in the predation experiments were assessed by using a Student's $t$-test after confirming the population of two tested groups are normally distributed with equal variance. The occurrence rate of ossicle-detected and not-detected was compared between male and female using a chi-square test. Relationships between the 

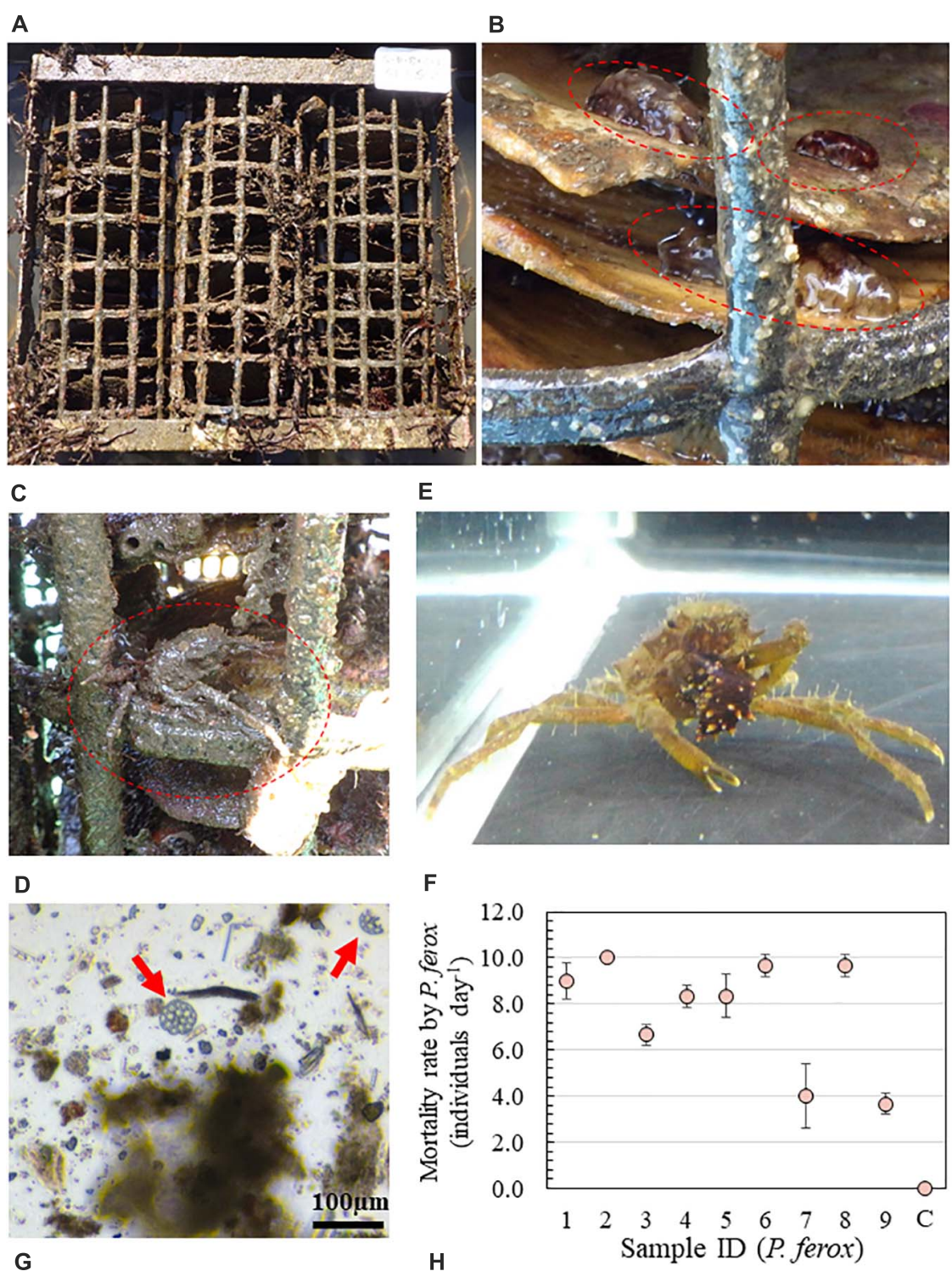

G

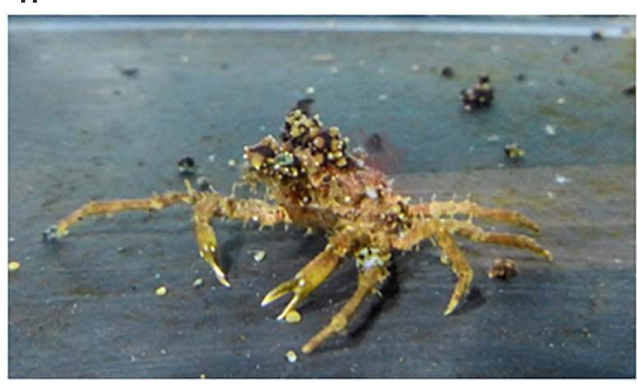

FIGURE 1 | (A) An artificial intermediate sea cucumber reef for releasing hatchery-produced juvenile Apostichopus japonicus. (B) Attached juvenile A. japonicus ( $\bigcirc)$ on scallop shells as a substrate within the reef. (C) Observed Pugettia ferox $(\bigcirc)$ within the same reef. (D) Ossicles of $A$. japonicus detected from the stomach contents of $P$. ferox. (E) Active predation of juvenile $A$. japonicus by $P$. ferox. (F) Results of the laboratory predation experiments. An aquaria with no $P$. ferox was used as a control (C). (G) Picture of $A$. japonicus killed by a female $P$. ferox within the first $2 \mathrm{~h}$. (H) Decoration of $P$. ferox using pieces of chopped sea cucumber.

mortality rate and all four body size indexes (CW, PCL, CPL, and wet weight) were examined using correlation analyses (Pearson's correlation coefficient) to determine if two numeric variables are significantly linearly related. The statistical analyses were performed using StatView statistical software (version 5.0) and $R$ version 3.6.2. 


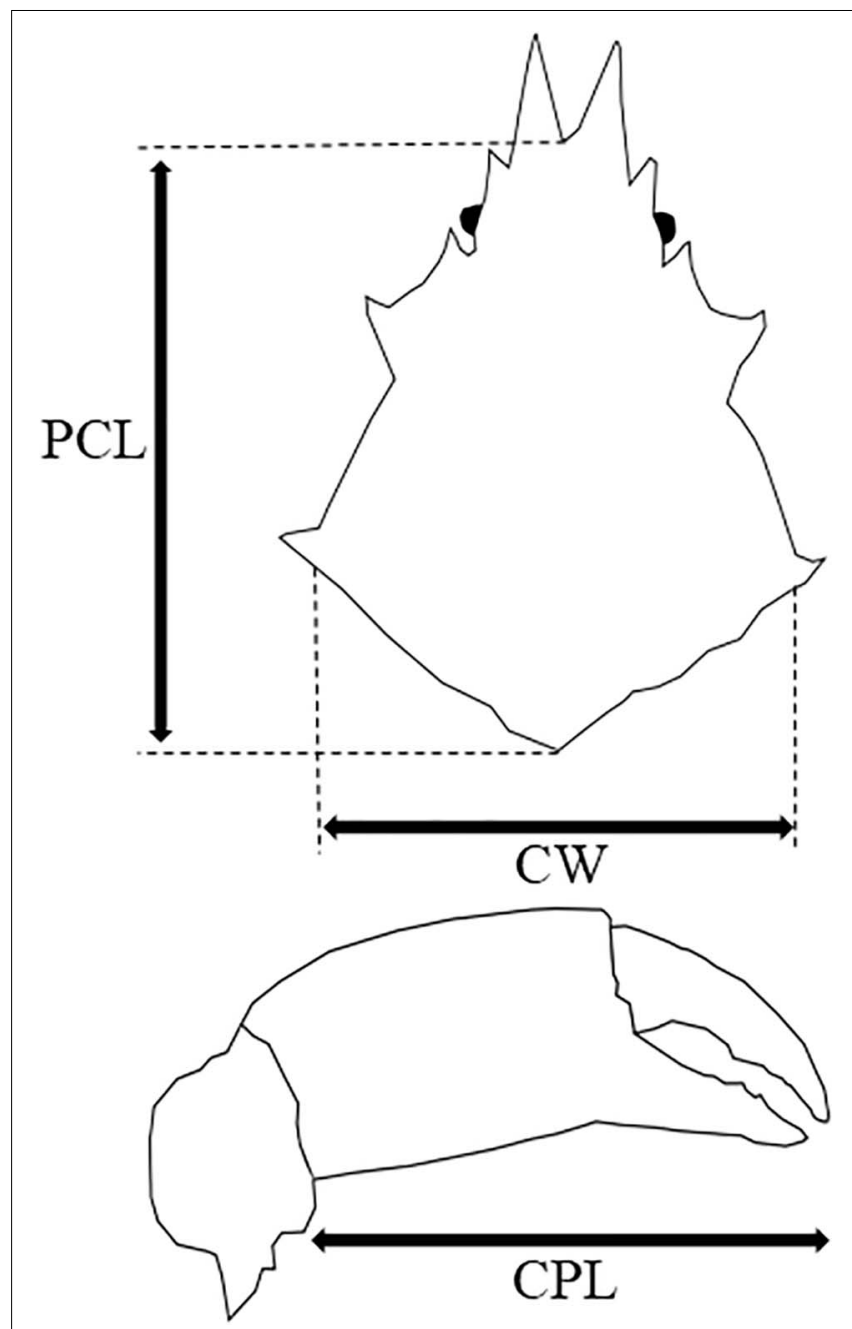

FIGURE 2 | Maximum carapace width (CW), post-pseudorostral carapace length (PCL), and cheliped propodus length (CPL) of $P$. ferox measured as body size indexes.

\section{RESULTS}

\section{Measurement of $P$. ferox and \\ A. japonicus Ossicle in Stomach Content}

Averages of CW, PCL, and wet weight of the collected P. ferox were $13.40 \pm 5.40 \mathrm{~mm}$ (Mean $\pm \mathrm{SD}$ ) varied from 4.08 to $25.26 \mathrm{~mm}, 18.45 \pm 6.34 \mathrm{~mm}$ varied from 6.42 to $34.71 \mathrm{~mm}$, and $1.73 \pm 2.05 \mathrm{~g}$ varied from 0.03 to $9.42 \mathrm{~g}$, respectively. The ossicles of $A$. japonicus were detected from the stomach contents at a rate of $32.4 \%$, and averages of CW, PCL, and wet weight of P. ferox containing ossicles were $12.53 \pm 3.00 \mathrm{~mm}$ varied from 6.80 to $20.33 \mathrm{~mm}, 18.10 \pm 3.17 \mathrm{~mm}$ varied from 11.53 to $24.92 \mathrm{~mm}$, and $1.12 \pm 0.85 \mathrm{~g}$ varied from 0.18 to $4.11 \mathrm{~g}$, respectively. Although there were no statistically significant differences in body size indexes of CW, PCL in both male and female crabs, and wet weight in females between the ossicle-detected and not-detected groups ( $p>0.05)$, the average of wet weight between the ossicledetected and not-detected groups in male crabs $(p<0.05)$ were significantly different (Figure 3). Moreover, the ossicles were detected more frequently in females (1:1.44) despite the sex ratio of male and female P. ferox examined stomach contents was 1:0.94. No statistical significance was seen in the occurrence rate of ossicle-detected and not-detected groups between male and female crabs $(p>0.05)$.

\section{Mortality Rate and Predatory Behavior}

The high mortality rate $\left[7.7 \pm 2.4\right.$ individuals day $^{-1}$ (Mean $\pm \mathrm{SD}$ )] of juvenile $A$. japonicus was confirmed despite the various sizes and sexes of $P$. ferox beside no mortality in control (Figure 1F). Even though there were positive relationships between the mortality rate and all four body size indexes (CW, PCL, CPL, and wet weight) in the male crabs, no significant linear correlation was detected from either male or female crabs $(p>0.05)$. All crabs actively searched for food right after the start of experiments, and a maximum of five sea cucumbers was confirmed to be killed by a female $P$. ferox and cut into small pieces within the first $2 \mathrm{~h}$ (Figure 1G). Although tested P. ferox were confirmed to forage for food during the daytime, the number of A. japonicus killed during the night was significantly higher $(p<0.001)$. No statistical significance was confirmed in mortality rate between male and female and ontogenetic stages $(p>0.05)$. During experiments, all of the smaller and younger individuals (adolescent) between CWs of 14.2-17.8 mm actively decorated themselves using chopped sea cucumber pieces during and/or after feeding (Figure 1H). However, attached pieces of sea cucumber were observed to be fully eaten within a week in all experiments.

\section{DISCUSSION}

In general, holothurians, including A. japonicus, are known to have few predators (Francour, 1997), owing to wide-ranging anti-predator behaviors, including detachment, body shape change, shedding body parts, and toxicity, in exchange for their slow-moving behavioral characteristics (Mosher, 1956; Bakus, 1968; Kropp, 1982; Bingham and Braithwaite, 1986; Morton, 1991; Aminin, 2016; Kamyab et al., 2020). Indeed, upon attack by $P$. ferox, often observed antipredator behaviors by A. japonicus were the contractions of their body and detachments from the attached surface in this study. The contraction of A. japonicus is caused by external stimuli using catch connective tissue, which controls the body wall's stiffness for resisting predators (Motokawa, 1984). Some studies in Holothuria scabra and Stichopus horrens demonstrated successful escapes from predators by detachment (Kropp, 1982; Morton, 1991). On the other hand, Dance et al. (2003) reported heavy predations by fish after releasing juveniles of tropical sea cucumber Holothuria scabra to the wild, indicating the importance of evaluating impact by predators. Carnivorous fish, crabs, gastropods, and sea stars are suggested to be candidates as predators for A. japonicus juveniles (Francour, 1997; Yu et al., 2015), and sea star Asterina pectinifera is considered as the principal predator of A. japonicus 


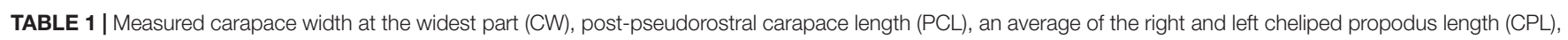
and wet weight of Pugettia ferox ( $n=9$, four Males, five Females) used in the laboratory predation experiments.

\begin{tabular}{|c|c|c|c|c|c|c|}
\hline Sample ID & Sex & Ontogenetic stage & Wet weight (g) & $\begin{array}{c}\text { Carapace width } \\
\text { (mm) }\end{array}$ & $\begin{array}{l}\text { Post-pseudorostral } \\
\text { carapace length } \\
(\mathrm{mm})\end{array}$ & $\begin{array}{c}\text { Cheliped propodus } \\
\text { length }(\mathrm{mm})\end{array}$ \\
\hline 1 & F (Female) & Adolescent & 1.34 & 14.2 & 17.1 & $8.3 \pm 0.7$ \\
\hline 2 & $\mathrm{~F}$ & Adolescent & 1.48 & 14.2 & 17.5 & $8.3 \pm 0.15$ \\
\hline 3 & M (Male) & Adolescent & 2.34 & 17.0 & 21.1 & $12.5 \pm 1.35$ \\
\hline 4 & $\mathrm{M}$ & Adolescent & 2.78 & 17.8 & 21.0 & $12.9 \pm 0.05$ \\
\hline 5 & $\mathrm{M}$ & Full-grown & 5.19 & 22.4 & 23.3 & $17.8 \pm 0.1$ \\
\hline 6 & $\mathrm{M}$ & Full-grown & 14.77 & 27.9 & 31.2 & $28.5 \pm 0.2$ \\
\hline 7 & $\mathrm{~F}$ & Full-grown & 3.14 & 16.0 & 22.1 & $9.5 \pm 0.3$ \\
\hline 8 & $\mathrm{~F}$ & Full-grown & 4.15 & 20.9 & 22.9 & $11.0 \pm 0.4$ \\
\hline 9 & $\mathrm{~F}$ & Full-grown & 2.66 & 15.8 & 20.2 & $8.2 \pm 0.05$ \\
\hline
\end{tabular}

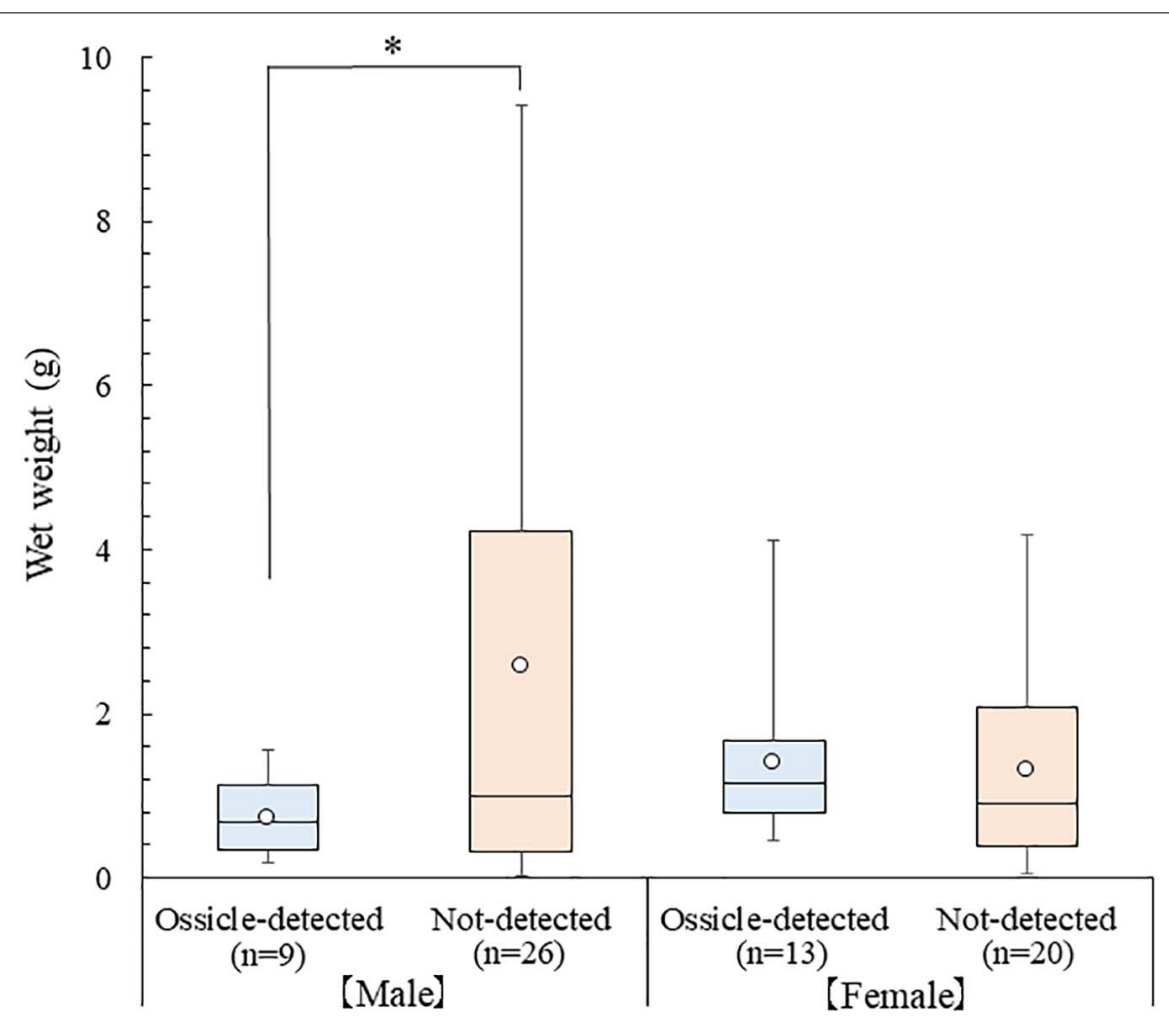

FIGURE 3 | Box plot of wet weight between the ossicle-detected and not-detected groups in male and female $P$. ferox collected within artificial intermediate sea cucumber reefs for releasing hatchery-produced juveniles in December 2018. An open circle (○) represents the average wet weight. The top and the bottom line of the box show the first and third quartiles, and the middle line is the median. The upper (lower) whisker displays the maximum (minimum) value. Asterisk $(*)$ indicates statistical significance $(p<0.05)$.

juvenile, ingesting 1.8 individuals with an average length of $15.9 \mathrm{~mm}$ on average per day in laboratory experiments (Hatanaka et al., 1994). In the present study, the calculated mortality rate of $7.7 \pm 2.4$ A. japonicus individuals $(15.35 \pm 2.47 \mathrm{~mm})$ per day by $P$. ferox was over four times higher than Asterina pectinifera, suggesting the importance of specifying potential predators as well as evaluating their impact. Considering spatial distribution and habitat overlap of the two species (Liu, 2015; Ohtsuchi and Kawamura, 2019), the presented phenomenon may be widespread in the natural environment. Thus, the future investigation of relatively unknown ecological information of $P$. ferox may be crucial for the areas putting efforts into recovering wild stocks of A. japonicus, and/or establishing efficient release methods of hatchery-produced $A$. japonicus juvenile.

In general, body size, ontogenetic stages, and sex are essential determinants influencing the feeding behaviors of brachyuran crabs (Kolts et al., 2013; Williner and Collins, 2013). For instance, larger males could consume larger prey, but female and smaller male crabs may be more efficient feeders, depending on their handling ability and strength (Kolts et al., 2013; Tina et al., 2015). 
In the present study, the ossicles were detected more frequently in females with a broader size range, and no ossicle was found in male crabs over $15 \mathrm{~mm}$ in CW (ca. $1.56 \mathrm{~g}$ in wet weight). Together with the high mortality rate of female crabs confirmed in laboratory study, these results indicate female $P$. ferox pose a greater risk on juvenile $A$. japonicus than males. Regarding the size of sea cucumber, Purcell and Simutoga (2008) documented that size at release significantly affected the survival of juvenile sandfish Holothuria scabra by predation. The predation by sea star Asterina pectinifera was substantially reduced when A. japonicus juveniles with an average length of $30.1 \mathrm{~mm}$ compared with an average length of $15.9 \mathrm{~mm}$ (Hatanaka et al., 1994). Therefore, sex and ontogeny-related feeding behaviors and the predator-prey body size relationships may need to be carefully investigated as a future task for a more accurate evaluation of the impact on $A$. japonicus by $P$. ferox.

Pugettia ferox is referred to as decorator crab, using their specialized setae to hook extraneous materials from the environment for use as camouflage (Ohtsuchi and Kawamura, 2019). The functions of decoration camouflage are to reduce the probability of detection, recognition, and consumption by predators (Hultgren and Stachowicz, 2011). P. ferox utilize various combinations of pieces of red and brown algae, branched colonies of bryozoans, or hydrozoans for their decoration materials (Ohtsuchi and Kawamura, 2019). In the present study, all of the smaller and younger (adolescent) $P$. ferox actively used chopped sea cucumber pieces to decorate themselves during and/or after feeding (Figure $\mathbf{1 H}$ and Supplementary Movie 2). Our observation was consistent with the decoration behavior of other brachyuran crabs that juvenile decorated more frequently than adult (Hultgren and Stachowicz, 2009; De Carvalho et al., 2016), explained with their susceptibility to predation and habitat changes (Todd et al., 2009). There are also crabs known to decorate with noxious organisms, such as algae, sponges, or other invertebrates, to deter predators (Stachowicz and Hay, 1999). A. japonicus produce saponins, which act as a feeding deterrent and/or warning effect to potential predators (Van Dyck et al., 2011). Assuming that P. ferox exhibit the same decorating behavior using A. japonicus in nature, the risk of feeding pressure by predators may be significantly reduced. However, decorated pieces of sea cucumbers were fully eaten within a week when no food was given thereafter. In this regard, our observation was rather similar to the results presented by

\section{REFERENCES}

Akamine, J. (2004). "The status of the sea cucumber fisheries and trade in Japan: past and present," in Advances in Sea Cucumber Aquaculture and Management, eds A. Lovatelli, C. Conand, S. Purcell, S. Uthicke, J.-F. Hamel, and A. Mercier (Rome: FAO), 39-47. Fisheries Technical Paper No. 463.

Akamine, J. (2015). Apostichopus japonicus: fisheries, trade, and foodways in Japan. Dev. Aquacult. Fish. Sci. 39, 399-421. doi: 10.1016/B978-0-12-799953-1.00 $022-2$

Aminin, D. (2016). "Immunomodulatory properties of sea cucumber triterpene glycosides," in Marine and Freshwater Toxins, eds P. Gopalakrishnakone, V. Haddad, Jr., A. Tubaro, E. Kim, and W. Kem (Dordrecht: Springer), 381-401.

Bakus, C. J. (1968). Defensive mechanisms and ecology of some tropical holothurians. Mar. Biol. 2, 23-32. doi: 10.1007/BF00351634
Woods and Mclay (1994) that the attached materials take a role as short-term food storage and/or play multiple roles (Hay, 1992). It is intriguing to deepen our knowledge on these novel and unique ecological traits of decoration in reaction to the presence or absence of predators and food resources in order to understand adaptation and natural selection of $P$. ferox, as well as offering an important perspective on A. japonicus fishery.

\section{DATA AVAILABILITY STATEMENT}

The original contributions presented in the study are included in the article/Supplementary Material, further inquiries can be directed to the corresponding author.

\section{AUTHOR CONTRIBUTIONS}

NI and HK conceived and designed the research. NI, TM, and YA performed the fieldwork. NI and KM analyzed the data and wrote the manuscript with essential contribution from all authors.

\section{ACKNOWLEDGMENTS}

We express sincere gratitude to the members of Fisheries Engineering Research Team, Civil Engineering Research Institute for Cold Region (CERI), Japan, for administrative support, especially Sawako Shirai, a technical assistant. We would also like to show our great appreciation to Emeritus professor Ichiro Imai from Hokkaido University for critical advice and Naoya Ohtsuchi from International Coastal Research Center, University of Tokyo, for essential advice about $P$. ferox identification. Our sincere appreciation goes to Atsushi Yamaguchi from Hokkaido University for providing laboratory space during the investigation.

\section{SUPPLEMENTARY MATERIAL}

The Supplementary Material for this article can be found online at: https://www.frontiersin.org/articles/10.3389/fmars. 2021.684989/full\#supplementary-material

Battaglene, S. C. (1999). Culture of tropical sea cucumbers for the purposes of stock restoration and enhancement. Naga ICLARM Q. 22, 4-11.

Bell, J. D., Munro, J. L., Nash, W. J., Rothlisberg, P. C., Loneragan, N. R., Ward, R. D., et al. (2005). Restocking and stock enhancement of marine invertebrate fisheries. Adv. Mar. Biol. 49, xi-374. doi: 10.1016/S0065-2881(05)49010-0

Bingham, B. L., and Braithwaite, L. F. (1986). Defense adaptations of the dendrochirote holothurian Psolus chitonoides Clark. J. Exp. Mar. Biol. Ecol. 98, 311-322. doi: 10.1016/0022-0981(86)90220-0

Brown, N. P., and Eddy, S. D. (2015). Echinoderm Aquaculture. Hoboken, NJ: Wiley.

Choo, P. S. (2008). "Population status, fisheries and trade of sea cucumbers in Asia," in Sea Cucumbers. A Global Review of Fisheries and Trade, eds V. ToralGranda, A. Lovatelli, and M. Vasconcellos (FAO: Rome), 81-118. Fisheries and Aquaculture Technical Paper No. 516. 
Dance, S., Lane, I., and Bell, J. D. (2003). Variation in short-term survival of cultured sandfish (Holothuria scabra) released in mangrove-seagrass and coral reef flat habitats in Solomon Islands. Aquaculture 220, 495-505. doi: 10.1016/ S0044-8486(02)00623-3

De Carvalho, F., Costa, T., Barreto, R., and de Oliveira Rodrigues, R. (2016). Decoration behaviour in a spider crab, Acanthonyx scutiformis (Dana, 1851) in relation to life stage, sex and algal species. Crustaceana 89, 775-786. doi: 10.1163/15685403-00003539

Francour, P. (1997). Predation on holothurians: a literature review. Invertebr. Biol. 116, 52-60. doi: 10.2307/3226924

Gosselin, L., and Qian, P. (1997). Juvenile mortality in benthic marine invertebrates. Mar. Ecol. Prog. Ser. 146, 265-282. doi: 10.3354/meps146265

Hatanaka, H., and Tanimura, K. (1994). Application of menthol as an anesthetizer for body size measuring sea-cucumber juveniles. Suisanzoshoku 42, 221-225. doi: 10.11233/aquaculturesci1953.42.221

Hatanaka, H., Uwaoku, H., and Yasuda, T. (1994). Experimental studies on the predation of juvenile sea cucumber, Stichopus japonicus by sea star, Asterina pectinifera. Suisanzoshoku 42, 563-566. doi: 10.11233/ AQUACULTURESCI1953.42.563

Hay, M. (1992). "The role of seaweed chemical defenses in the evolution of feeding specialization and in the mediation of complex interactions," in Ecological Roles of Marine Natural Products, ed. V. J. Paul (New York, NY: Cornell University Press), 93-118.

Hokkaido Government, (2020). Hokkaido Fisheries Today. Hokkaido: Department of Fisheries and Forestry.

Hoshikawa, H. (2003). Laboratory observations of predation by three starfishes and one crab on hatchery reared juveniles of the abalone, Haliotis discus hannai. Sci. Rep. Hokkaido Fish. Exp. Stn. 64, 121-126.

Hultgren, K., and Stachowicz, J. (2009). Evolution of decoration in majoid crabs: a comparative phylogenetic analysis of the role of body size and alternative defensive strategies. Amer. Nat. 173, 566-578. doi: 10.1086/597797

Hultgren, K., and Stachowicz, J. (2011). "Camouflage in decorator crabs: integrating ecological, behavioral and evolutionary approaches," in Animal Camouflage: Mechanisms and Function, eds M. Stevens, and S. Merilaita (Cambridge: Cambridge University Press), 212-236.

Kamyab, E., Rohde, S., Kellermann, M., and Schupp, P. (2020). Chemical defense mechanisms and ecological implications of Indo-Pacific Holothurians. Molecules 25:4808. doi: 10.3390/molecules25204808

Kawai, T., and Agatsuma, Y. (1996). Predators on released seed of the sea urchin, Strongylocentrotus intermedius at Shiribeshi, Hokkaido, Japan. Fish. Sci. 62, 317-318. doi: 10.2331/fishsci.62.317

Kolts, J., Lovvorn, J., North, C., Grebmeier, J., and Cooper, L. (2013). Effects of body size, gender, and prey availability on diets of snow crabs in the northern Bering Sea. Mar. Ecol. Prog. Ser. 483, 209-220. doi: 10.3354/meps10292

Kropp, R. K. (1982). Responses of five holothurian species to attacks by a predatory gastropod, Tonna perdix. Pac. Sci. 36, 445-452.

Liu, J. (2015). "Spatial distribution, population structures, management, and cinservation," in The Sea Cucumber Apostichopus japonicus: History, Biology and Aquaculture, eds H. S. Yang, J. F. Hamel, and A. Mercier (Amsterdam: Academic Press), 77-86.

Mercier, A., and Hamel, J.-F. (2013). Apostichopus japonicus. The IUCN Red List of Threatened Species 2013. Available online at: https://dx.doi.org/10.2305/IUCN. UK.2013-1.RLTS.T180424A1629389.en (accessed October 1, 2020).

Morton, B. (1991). Aspects of predation by Tonna zonatum (Prosobranchia: Tonnoidea) feeding on holothurians in Hong-Kong. J. Molluscan Stud. 57, 11-19. doi: 10.1093/mollus/57.1.11

Mosher, C. (1956). Observation on evisceration and visceral regeneration in the sea cucumber Actinopyga agassizi Selenka. Zoologica 41, 17-26.

Motokawa, T. (1984). Connective tissue catch in echinoderms. Biol. Rev. 59, 255-270. doi: 10.1111/j.1469-185X.1984.tb00409.x
Ohtsuchi, N., and Kawamura, T. (2019). Redescriptions of Pugettia quadridens (De Haan, 1837) and P. intermedia Sakai, 1938 (Crustacea: Brachyura: Epialtidae) with description of a new species. Zootaxa 4672, 1-68. doi: 10.11646/zootaxa. 4672.1.1

Purcell, S. W. (2004). "Criteria for release strategies and evaluating the restocking of sea cucumbers," in Advances in Sea Cucumber Aquaculture and Management, eds A. Lovatelli, C. Conand, S. Purcell, S. Uthicke, J.-F. Hamel, and A. Mercier (Rome: FAO), 181-191. Fisheries Technical Paper No. 463.

Purcell, S., and Simutoga, M. (2008). Spatio-temporal and size-dependent variation in the success of releasing cultured sea cucumbers in the wild. Rev. Fish. Sci. Aquac. 16, 204-214. doi: 10.1080/10641260701686895

Purcell, S., Mercier, A., Conand, C., Hamel, J.-F., Toral-Granda, M. V., Lovatelli, A., et al. (2013). Sea cucumber fisheries: global analysis of stocks, management measures and drivers of overfishing. Fish Fish. 14, 34-59. doi: 10.1111/j.14672979.2011.00443.x

Shibui, T. (1971). Experimental studies on the predatory animals of young abalone. Bull. Jpn. Soc. Sci. Fish. 37, 1173-1176. doi: 10.2331/SUISAN.37.1173

Stachowicz, J., and Hay, M. (1999). Reducing predation through chemically mediated camouflage: indirect effects of plant defenses on herbivores. Ecology 80, 495-509. doi: 10.2307/176628

Tina, F., Jaroensutasinee, M., and Jaroensutasinee, K. (2015). Effects of sexual dimorphism and body size on feeding behaviour of the fiddler crab, Uca bengali Crane, 1975. Crustaceana 88, 231-242. doi: 10.1163/15685403-00003405

Todd, P., Qiu, W., and Chong, K. (2009). Ontogenetic shifts in carapace patterning and/or colouration in intertidal and subtidal brachyuran crabs. Raffles Bull. Zool. 57, 543-550.

Van Dyck, S., Caulier, G., Todesco, M., Gerbaux, P., Fournier, I., Wisztorski, M., et al. (2011). The triterpene glycosides of Holothuria forskali: usefulness and efficiency as a chemical defense mechanism against predatory fish. J. Exp. Biol. 214, 1347-1356. doi: 10.1242/jeb.050930

Williner, V., and Collins, P. A. (2013). Feeding ecology of the freshwater crab Trichodactylus borellianus (Decapoda: Trichodactylidae) in the floodplain of the Paraná River, southern South America. Lat. Am. J. Aquat. Res. 41, 781-792.

Woods, C., and Mclay, C. (1994). Use of camouflage materials as a food store by the spider crab Notomithrax ursus (Brachyura: Majidae). N. Z. J. Mar. Freshw. Res. 28, 97-104. doi: 10.1080/00288330.1994.9516598

Yamana, Y., Goshima, S., Hamano, T., Yusa, T., Furukawa, Y., and Yoshida, N. (2011). Formulae to estimate standard body length for regional forms of the sea cucumber Apostichopus japonicus in Japan. Nippon Suisan Gakkaishi 77, 989-998. doi: 10.2331/SUISAN.77.989

Yu, Z., Yang, H., and Hamel, J. F. (2015). “Larval, juvenile, and adult predators," in The Sea Cucumber Apostichopus japonicus: History, Biology and Aquaculture, eds H. S. Yang, J. F. Hamel, and A. Mercier (Amsterdam: Academic Press), 243-256.

Conflict of Interest: YA was employed by the company Ocean Construction Co., Ltd.

The remaining authors declare that the research was conducted in the absence of any commercial or financial relationships that could be construed as a potential conflict of interest.

Copyright (c) 2021 Inaba, Matsumoto, Kawai, Anaguchi and Matsuno. This is an open-access article distributed under the terms of the Creative Commons Attribution License (CC BY). The use, distribution or reproduction in other forums is permitted, provided the original author(s) and the copyright owner(s) are credited and that the original publication in this journal is cited, in accordance with accepted academic practice. No use, distribution or reproduction is permitted which does not comply with these terms. 